\title{
Technologie spawalnicze podczas remontu pieca obrotowego w cementowni
}

\author{
Welding Technology \\ during the renovation of the cement rotary kiln
}

\section{Streszczenie}

W referacie przedstawiono przebieg procesu wymiany fragmentu pieca cementowego na podstawie doświadczeń ze zlecenia nadzoru nad pracami spawalniczymi prowadzonymi w zakresie ww. wymiany. Proces wymiany obejmuje dwa etapy. Pierwszy to przygotowanie dwóch zestawów carg w ramach prac przygotowawczych, ich montaż i spawanie. Drugi to wycięcie i usunięcie fragmentu pieca przeznaczonego do wymiany oraz zamontowanie i wspawanie nowych segmentów. Zwrócono również uwagę na trudności technologiczne oraz konieczność posiadania niezbędnego doświadczenia w prowadzeniu tego typu prac.

Słowa kluczowe: piec obrotowy, spawanie carg, nadzorowanie spawania

\section{Abstract}

The paper shows the process of exchanging part of cement kiln, which based on the experiences of supervision orders welding operations carried out in the range of the above exchange. The exchange process consists of two steps. The first is to prepare two sets of girdles during its preparatory work, their instalation and welding. The second is the cutting and removal part of the kiln to be replaced and the fitting and welding a new segment. Brought to the attention to technological difficulties and the need to have the necessary experience in conducting this type of work.

Keywords: rotary kiln, welding girdles, welding inspection

\section{Wstęp}

Cement to mineralne spoiwo hydrauliczne, które twardnieje po zarobieniu z wodą. Jest używane do zapraw budowlanych i betonów. Pod względem chemicznym cement tworzą pierwiastki powszechnie występujące w przyrodzie, takie jak: wapń, krzem, glin, żelazo i tlen.

Surowiec do wytworzenia cementu po dostarczeniu z kopalni jest kruszony i wstępnie uśredniany. Składniki surowca do przemiału na mąkę dozowane są w ściśle określonych proporcjach. Utrzymanie stałego składu surowca przygotowanego do wypału w piecu jest podstawą otrzymania dobrego produktu - klinkieru cementowego.

Po przejściu surowca przez młyny powstaje mączka, która po podgrzaniu wprowadzona jest do pieca obrotowego. Proces wypalania w temperaturze ok. $1450{ }^{\circ} \mathrm{C}$ powoduje powstanie klinkieru cementowego, z którego po zmieleniu wraz z dodatkami (gips, popioły, żużle itp.) otrzymuje się cement.

Piec obrotowy to walczak o średnicy od 4500 do $6000 \mathrm{~mm}$, zróżnicowanej grubości ścianek, długości do 100 m, ułożony poziomo pod kątem $2 \div 5^{\circ}$. Pochylenie to powoduje przemieszczanie się surowca wzdłuż osi poziomej pieca podczas jego obrotu (rys. 1).

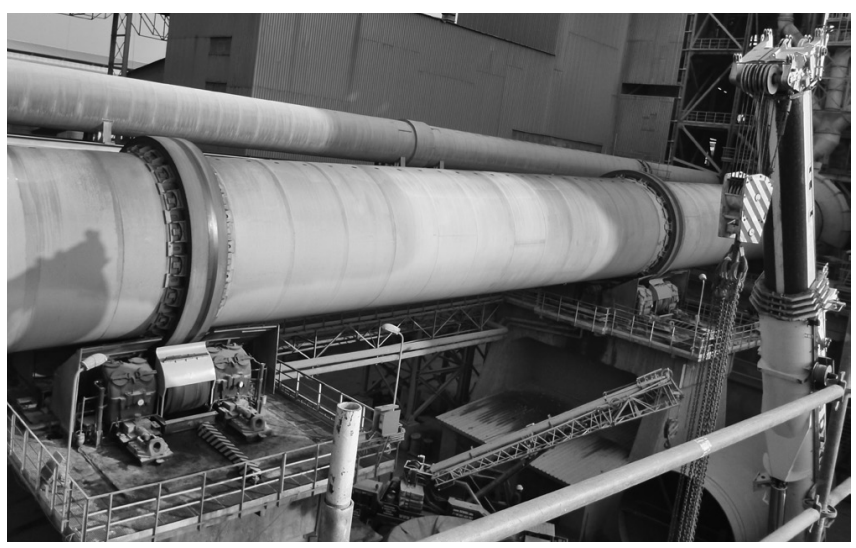

Rys. 1. Piec obrotowy

Fig. 1. Rotary kiln

\section{Zakres remontu}

Walczak pieca podczas eksploatacji ulega deformacjom i zużyciu. Szczególnie wówczas gdy nastąpi zbyt duży ubytek ogniotrwałej wymurówki wewnątrz pieca lub jej awaryjne wykruszenie się. 
W omawianym przypadku piec posiada średnicę wewnętrzną 5000 mm i długość 90 m. Grubości ścianek walczaka w części objętej wymianą to 40 i $45 \mathrm{~mm}$. Odcinek pieca przewidziany do wymiany miał długość $28 \mathrm{~m}$. Stal, z którego wykonane są cargi pieca to P265GH, której charakterystykę przestawiono w tablicy I.

Nowe elementy pieca (cargi) dostarczone do cementowni miały długość 2 i 3 m oraz grubość 40 i 45 mm. Każda carga zabezpieczona została przez jej wytwórcę rozporami zapobiegającymi przez jej deformacją.

W technologii remontu przewidziano scalenie dwóch segmentów (po 5 carg każdy) podczas prac przygotowawczych (rys. 2). Następnie segmenty te wraz z dwoma dodatkowymi cargami, należało zamontować w miejsce usuniętego fragmentu pieca.

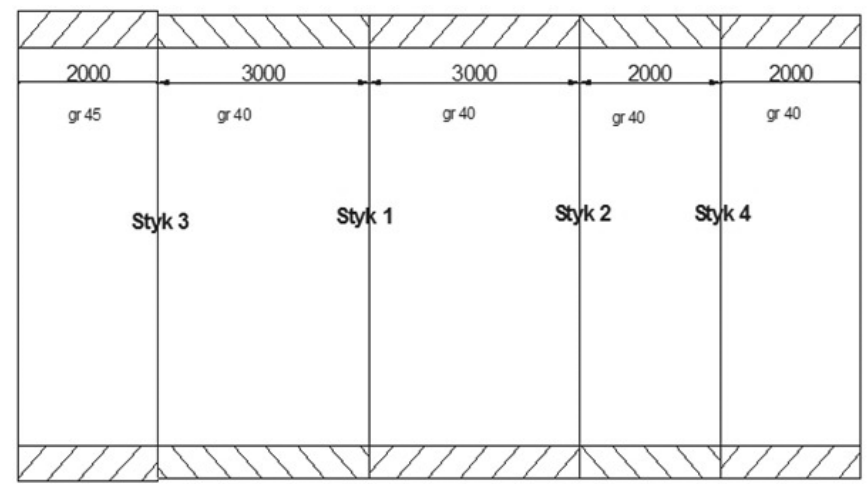

Rys. 2. Rysunek segmentu złożonego z pięciu carg

Fig. 2. Picture of segment composed of five girdles

\section{Personel}

Zgodnie z zatwierdzonym przez cementownię planem remontu, za całość zleconych prac odpowiadał kierownik budowy. Bezpośrednio pracami kierował mistrz budowy, a prace spawalnicze nadzorował inżynier spawalnik. Personel nadzoru posiadał odpowiednie doświadczenie w wykonywaniu prac objętych zakresem remontu.

Dość znacznym problemem okazało się skompletowanie wymaganej liczby spawaczy. Ze względu na to, że firma wykonująca remont (doświadczona w wykonywaniu tego typu prac) nie posiadała w swych zasobach wystarczającej liczby spawaczy, koniecznym było zatrudnienie spawaczy od innych podwykonawców. W tym celu ustalono system weryfikacji spawaczy. Dobór ten polegał na:

- zweryfikowaniu posiadanych uprawnień spawaczy - wymagane aktualne uprawnienie dla metody 111 i 135 wg EN 287-1[3] lub EN ISO 9606-1[4] do wykonywania złączy doczołowych o grubości 40 i $45 \mathrm{~mm}$ w pozycjach PA i PF, grupa materiałowa 1.1;

- obligatoryjnie każdy spawacz wykonywał doczołowe złącze próbne, grubości min $30 \mathrm{~mm}$, w pozycjach PA i PF. Złącza poddawane były badaniom ultradźwiękowym i oraz próbom zginania.

Pomimo posiadania wymaganych uprawnień, badania próbek znacznej części spawaczy dawały wynik negatywny. Świadczy to o braku umiejętności, tychże spawaczy, do wykonywania złączy doczołowych o większych grubościach. Do prac dopuszczeni zostali tylko spawacze, którzy pozytywnie przeszli powyższą weryfikację. Na rysunku 3 przedstawiono przykład próbek po próbie gięcia.
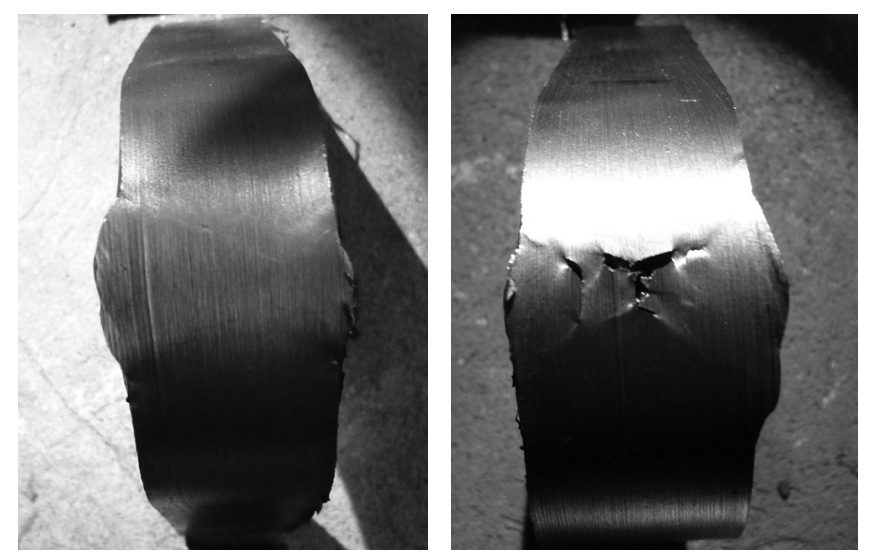

Rys. 3. Próbki po próbie gięcia

Fig. 3. Samples after bend test

\section{Spawanie segmentów w ramach prac przygotowawczych}

Przedstawiony proces spawania wykonywany był zgodnie z kwalifikowanymi i zaakceptowanymi przez zlecającego (cementownię) technologiami spawania. Na ich podstawie opracowano niezbędne instrukcje spawania (WPS). Z ich wymaganiami zapoznano wszystkich pracowników biorących udział w pracach spawalniczych (monterów, szlifierzy, spawaczy).

Tablica I. S Skład chemiczny stopiwa FCW 2205-H

Table I. Chemical composition of FCW 2205-H

\begin{tabular}{|c|c|c|c|c|c|c|c|c|c|c|c|c|c|}
\hline \multicolumn{14}{|c|}{ Skład pierwiastków stopowych (\%) } \\
\hline $\mathrm{C}$ & Si & $\mathrm{Mn}$ & $\mathrm{Ni}$ & $\mathrm{P}$ & S & $\mathrm{Cr}$ & Mo & V & $\mathrm{N}$ & $\mathrm{Nb}$ & $\mathrm{Ti}$ & $\mathrm{Al}$ & $\mathrm{Cu}$ \\
\hline $\begin{array}{c}\max \\
0,2\end{array}$ & $\begin{array}{c}\max \\
0,4\end{array}$ & $0,8-1,4$ & $\begin{array}{c}\max \\
0,3\end{array}$ & $\begin{array}{c}\max \\
0,025\end{array}$ & $\begin{array}{c}\max \\
0,015 \\
\end{array}$ & $\begin{array}{c}\max \\
0,3\end{array}$ & $\begin{array}{c}\max \\
0,8\end{array}$ & $\begin{array}{l}\max \\
0,02\end{array}$ & $\begin{array}{c}\max \\
0,012\end{array}$ & $\begin{array}{l}\max \\
0,02\end{array}$ & $\begin{array}{l}\max \\
0,03\end{array}$ & $\begin{array}{l}\max \\
0,02\end{array}$ & $\begin{array}{c}\max \\
0,3 \\
\end{array}$ \\
\hline \multicolumn{14}{|c|}{$\mathrm{Cr}+\mathrm{Cu}+\mathrm{Mo}+\mathrm{Ni}<0,7 \%$} \\
\hline \multicolumn{8}{|c|}{ Nominalna grubość (mm): } & \multicolumn{2}{|c|}{ do 100} & \multicolumn{2}{|c|}{$100-150$} & \multicolumn{2}{|c|}{$150-250$} \\
\hline \multicolumn{8}{|c|}{ Rm - wytrzymałość na rozciąganie (MPa) } & \multicolumn{2}{|c|}{$410-530$} & \multicolumn{2}{|c|}{$400-530$} & \multicolumn{2}{|c|}{$390-530$} \\
\hline \multicolumn{8}{|c|}{ Nominalna grubość (mm) } & do 16 & $16-40$ & $40-60$ & $60-100$ & $100-150$ & $150-250$ \\
\hline \multicolumn{8}{|c|}{ Re - ganica plastyczności (MPa) } & 265 & 255 & 245 & 215 & 200 & 185 \\
\hline \multicolumn{8}{|c|}{ KV - praca łamania $(\mathrm{J})$ w kierunku poprzecznym } & \multicolumn{2}{|c|}{$\begin{array}{c}-20^{\circ} \\
27\end{array}$} & \multicolumn{2}{|c|}{$\begin{array}{l}0^{\circ} \\
27\end{array}$} & \multicolumn{2}{|c|}{$\begin{array}{r}+20^{\circ} \\
40\end{array}$} \\
\hline \multicolumn{8}{|c|}{ KV - praca łamania $(J)$ w kierunku wzdłużnym } & \multicolumn{2}{|c|}{$\begin{array}{c}-10^{\circ} \\
28 \\
\end{array}$} & \multicolumn{2}{|c|}{$\begin{array}{l}0^{\circ} \\
40 \\
\end{array}$} & \multicolumn{2}{|c|}{$\begin{array}{r}+20^{\circ} \\
47 \\
\end{array}$} \\
\hline \multicolumn{8}{|c|}{ A - wydłużenie (\%) w kierunku poprzecznym } & \multicolumn{6}{|c|}{21} \\
\hline \multicolumn{8}{|c|}{ A- wydłużenie (\%) w kierunku wzdłużnym } & \multicolumn{6}{|c|}{-} \\
\hline
\end{tabular}


Po oczyszczeniu brzegów carg o średnicy 5000 mm grubości 40 oraz $45 \mathrm{~mm}$ (rys. 4a i 4b) ustawiono na obrotniku rolkowym 3 cargi i przeprowadzono pomiary geometryczne wzajemnego ich ustawienia (rys. 4c). Cargi zdystansowano przy pomocy blach gr. $4 \mathrm{~mm}$ i unieruchomiono za pomocą śrub i jarzm od wewnętrznej strony płaszcza (rys. 4d i 5a). Dla tak przygotowanego zestawu przeprowadzono pomiary geodezyjne dla zapewnienia ich współosiowości. Nad całością ustawiono rusztowanie i przykryto je brezentową osłoną aby zabezpieczyć miejsce spawania przed niekorzystnymi warunkami atmosferycznymi tj. wiatr, opady (rys. 4a).
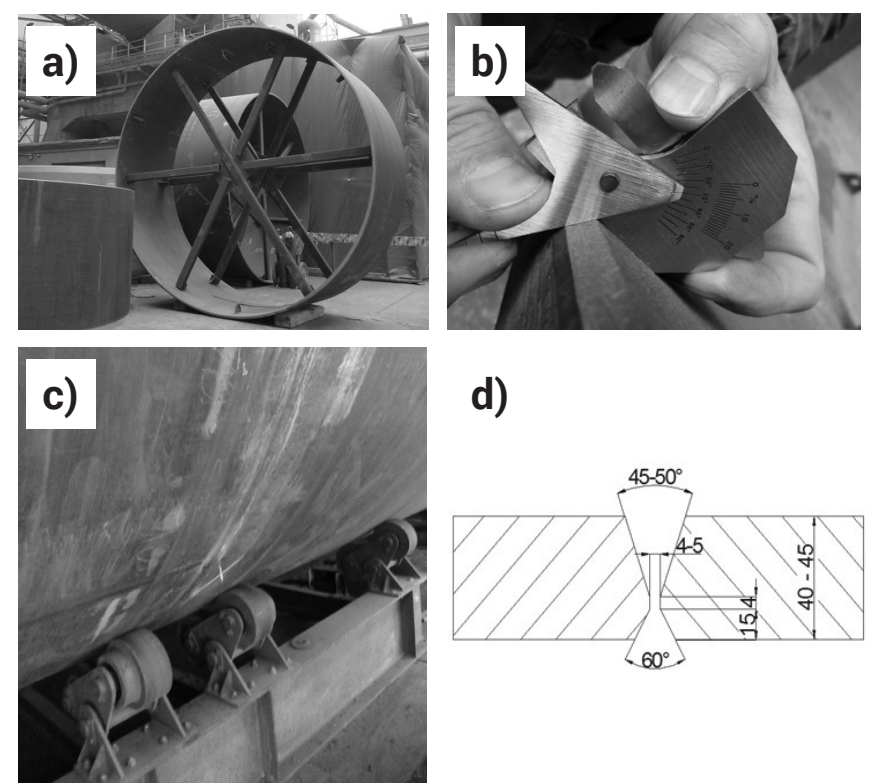

d)

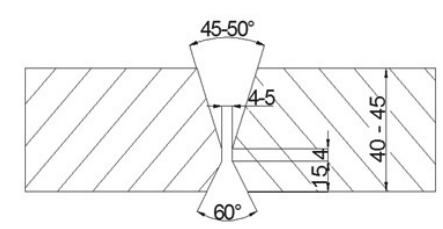

Rys. 4. przestawia: a) pojedynczą cargę i zabezpieczone miejsce spawania, b) przykład ukosowania brzegów carg, c) elementy ustawione na obrotniku, d) schemat przygotowania złącza

Fig. 4. (a) sningiel girdle and and secured a place welding, b) example of chamfering the edges of gridles, c)the elements set to the positioner, d) joint preparation scheme)

W miejscach wykonywania spoin sczepnych ustawiono promienniki gazowe zasilane propanem (rys. 5b). Po uzyskaniu temperatury minimum $100^{\circ} \mathrm{C}$ wykonano 8 spoin sczepnych, równomiernie rozłożonych po obwodzie, o długości ok. 500 mm każda. Spoiny układano symetrycznie po zewnętrznej stronie płaszcza, przez dwóch spawaczy jednocześnie. Proces podgrzewania prowadzony był przez cały okres spawania. Wartość temperatury sprawdzana była okresowo za pomocą pirometru optycznego. Podczas spawania sukcesywnie usuwano blachy dystansowe.
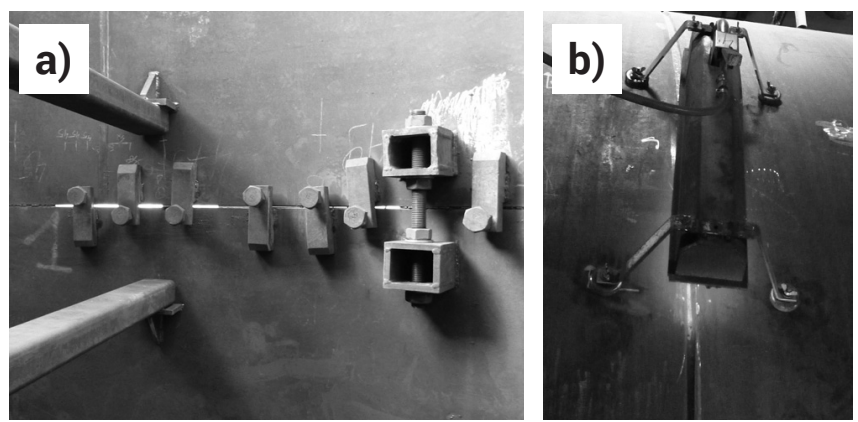

Rys. 5. Unieruchomione człony za pomocą jarzm b) nagrzewanie przed spawaniem

Fig. 5. heating before welding

Przed przystąpieniem do spawania warstwy przetopowej, spoiny sczepne zostały przebadane wizualnie pod względem możliwości wystąpienia pęknięć. W przypadkach niejednoznacznych przeprowadzano badania penetracyjne. Końce spoin sczepnych zostały zeszlifowane "na klin" w celu uzyskania łagodnego przejścia pomiędzy spoinami sczepnymi i spoiną przetopową. Warstwę przetopową oraz dwie kolejne warstwy (1,2,3 rys. 6) układano ręcznie, elektrodą otuloną BASOWELD 50-EVP 50p o średnicach 3,2 i $4 \mathrm{~mm}$ (tabl. II). Pozostałe warstwy wypełniające (4 do $\mathrm{n}$ rys. 6) wykonywano metodą MAG drutem OK AristoRod 13.09 $\emptyset 1,2 \mathrm{~mm}$ (tabl. III). Dla spawania metodą MAG stosowano mieszankę gazową $82 \% \mathrm{Ar}+18 \% \mathrm{CO}_{2}$.

W tablicach II i III przedstawiono charakterystyki wykorzystywanych materiałów dodatkowych.

Tablica II. Charakterystyka elektrody Metalweld BASOWELD 50 - EVB 50p Ø 3,2mm [5]

Table II. Characteristics of the electrode METALWELD BASOWELD 50 - EVB 50p Ø $3.2 \mathrm{~mm}$

\begin{tabular}{|c|c|c|c|}
\hline \multicolumn{4}{|c|}{ BASOWELD 50 - EVB 50p } \\
\hline $\begin{array}{l}\text { Typ otuliny: } \\
\text { Zasadowa }\end{array}$ & $\begin{array}{c}\text { Prąd spawania: } \\
\text { DC + }\end{array}$ & $\begin{array}{c}\text { Pozycje } \\
\text { spawania: } \\
\text { PA, PB, PC, } \\
\text { PD, PE, PF }\end{array}$ & $\begin{array}{c}\text { Ponowne } \\
\text { suszenie: } \\
300-350^{\circ} \mathrm{C} / 2 \mathrm{~h}\end{array}$ \\
\hline \multicolumn{4}{|c|}{ Typowy skład chemiczny stopiwa (w \%) } \\
\hline C 0,08 & \multicolumn{2}{|c|}{ Si 0,60} & Mn 1,0 \\
\hline \multicolumn{4}{|c|}{ Własności mechaniczne wg EN ISO 2560: } \\
\hline \multicolumn{2}{|c|}{ Plastyczność Rp 0,2\%: } & \multicolumn{2}{|c|}{$>420 \mathrm{~N} / \mathrm{mm}^{2}$} \\
\hline \multicolumn{2}{|c|}{ Wytrzymałość Rm: } & \multicolumn{2}{|c|}{$500-640 \mathrm{~N} / \mathrm{mm}^{2}$} \\
\hline \multicolumn{2}{|c|}{ Wydłużenie A5: } & \multicolumn{2}{|c|}{$>22 \%$} \\
\hline \multicolumn{2}{|c|}{ Udarność Av: } & \multicolumn{2}{|c|}{$90 \mathrm{~J}$ dla $-20^{\circ} \mathrm{C} \mathrm{i}>47 \mathrm{~J}$ dla $-40^{\circ} \mathrm{C}$} \\
\hline \multicolumn{2}{|c|}{ Zawartość wodoru w stopie } & \multicolumn{2}{|c|}{$<5 \mathrm{ml} / 100 \mathrm{~g}$} \\
\hline \multicolumn{4}{|c|}{ Parametry spawania } \\
\hline$\varnothing[\mathrm{mm}]$ & \multicolumn{2}{|c|}{ Długość [mm] } & Prąd $[A]$ \\
\hline 3,2 & \multicolumn{2}{|c|}{450} & $110-140$ \\
\hline
\end{tabular}

TablicallI.CharakterystykadrutuESABOKAristoRod13.09Ø1,2mm[6] Table III. Characteristics AristoRod wire ESAB OK $13.09 \emptyset 1.2 \mathrm{~mm}$

\begin{tabular}{|c|c|c|c|c|c|c|c|c|c|}
\hline \multicolumn{10}{|c|}{ OK AirstoRod 13.09} \\
\hline \multicolumn{4}{|c|}{ Prąd spawania: DC + } & \multicolumn{6}{|c|}{$\begin{array}{c}\text { Pozycje spawania: } \\
\text { PA, PB, PC, } \\
\text { PE, PF, PF }\end{array}$} \\
\hline \multicolumn{10}{|c|}{ Typowy skład chemiczny stopiwa (w\%): } \\
\hline \multicolumn{2}{|c|}{ C 0,10} & \multicolumn{2}{|c|}{ Si 0,60} & \multicolumn{2}{|c|}{ Mn 1,10 } & \multicolumn{4}{|c|}{ Mo 0,50} \\
\hline \multicolumn{10}{|c|}{ Typowe własności mechaniczne stopiwa } \\
\hline \multirow{2}{*}{ Stan } & \multirow{2}{*}{ Gaz } & \multirow{2}{*}{$\begin{array}{c}\text { Temp. } \\
\text { Bad. }\left[{ }^{\circ} \mathrm{C}\right]\end{array}$} & \multirow{2}{*}{$\stackrel{\mathrm{R}_{\mathrm{m}}}{[\mathrm{MPa}]}$} & \multirow{2}{*}{$\begin{array}{c}\mathrm{R}_{\mathrm{p} 0,2} \\
{[\mathrm{MPa}]}\end{array}$} & \multirow{2}{*}{ A5 [\%] } & \multicolumn{4}{|c|}{$\mathrm{KV}(\mathrm{J}) /{ }^{\circ} \mathrm{C}$} \\
\hline & & & & & & +20 & 0 & -20 & -40 \\
\hline \multirow{2}{*}{ TZ 0} & \multirow{6}{*}{ M21 } & +20 & 610 & 515 & 26 & 117 & - & 100 & 57 \\
\hline & & +450 & 570 & 425 & 20 & & & & \\
\hline \multirow{2}{*}{ TZ 1} & & +20 & 545 & 430 & 26 & 150 & 130 & 95 & 90 \\
\hline & & +450 & 490 & 370 & 23 & & & & \\
\hline \multirow{2}{*}{ TZ 2} & & +20 & 460 & 290 & 34 & 130 & 95 & 65 & 35 \\
\hline & & +450 & 470 & 220 & 25 & & & & \\
\hline
\end{tabular}

TZ 0 - po spawaniu, TZ 1 - po 0.C. $620^{\circ} \mathrm{C} / 15 \mathrm{~h}$,

TZ 2 - po normalizacji $940{ }^{\circ} \mathrm{C} / 0,5 \mathrm{~h}$.

\begin{tabular}{|c|c|c|c|c|c|c|}
\hline \multicolumn{7}{|c|}{ Parametry technologiczne } \\
\hline$\varnothing[\mathrm{mm}]$ & $\begin{array}{c}\text { Prąd } \\
\text { spawania } \\
{[\mathrm{A}]}\end{array}$ & $\begin{array}{c}\text { Napięcie } \\
\text { tuku } \\
{[\mathrm{V}]}\end{array}$ & $\begin{array}{c}\text { Wolny } \\
\text { wlot } \\
\text { drutu } \\
{[\mathrm{mm}]}\end{array}$ & $\begin{array}{c}\text { Przepływ } \\
\text { gazu } \\
{[1 / \mathrm{min}]}\end{array}$ & $\begin{array}{c}\text { Prędkość } \\
\text { podawania } \\
{[\mathrm{m} / \mathrm{min}]}\end{array}$ & $\begin{array}{c}\text { Wydaj- } \\
\text { ność } \\
\text { stopiwa } \\
{[\mathrm{kg} / \mathrm{h}]}\end{array}$ \\
\hline 1,2 & $120-350$ & $20-33$ & 20 & 18 & $2,7-12,4$ & $1,5-6,6$ \\
\hline
\end{tabular}


Warstwy przetopowe układano od zewnętrznej strony cargi, jednocześnie po przeciwnych stronach, następnie wykonywano obrót segmentu o $90^{\circ}$. Przed ułożeniem każdego ściegu, poprzedni podlegał czyszczeniu przy pomocy szczotki drucianej i szlifierki. Po wypełnieniu ok. 0,5 grubości zewnętrznego rowka spawalniczego, sukcesywnie usuwano jarzma i śruby ściągające za pomocą palnika acetylenowo-tlenowego. Miejsca po ich przyspawaniu wyszlifowano i rozpoczęto żłobienie grani (od strony wewnętrznej cargi) (rys. 6). Proces żłobienia przeprowadzany był za pomocą szlifierek. W celu sprawdzenia poprawności usunięcia niezgodności w warstwie graniowej wykonywano badania penetracyjne (rys. 7). Szlifowanie prowadzono do uzyskania wyników „bez wskazania” [9].

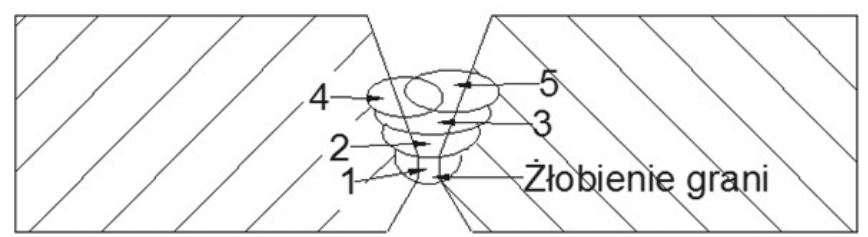

Rys. 6. Schemat spawania przed przystąpieniem do żłobienia grani Fig. 6. Scheme of prior to welding root gouging

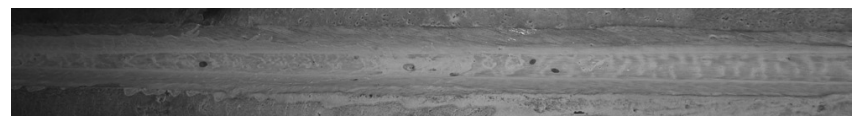

Rys. 7. Badania penetracyjne podczas usuwania warstwy graniowej Fig. 7. Penetration testing during removal melting layer

Po usunięciu grani prowadzono spawanie od wewnętrznej strony cargi. Układano dwie warstwy elektrodą otuloną (1', 2' rys. 8). Spawanie prowadzono po przeciwnych stronach płaszcza, następnie obracano segment $90^{\circ}$ i uzupełniano warstwę. Przed ułożeniem ściegu następnego poprzedni dokładnie oczyszczano przy pomocy szlifierki i szczotki. Podczas układania kolejnych warstw przestrzegano zasady przesunięcia końców sąsiednich ściegów o min 30 mm. Pozostałe warstwy wypełniające oraz licowe wykonywano metodą 135. Przez cały czas spawania utrzymywano temperaturę podgrzewania do spawania, okresowo kontrolując jej wartość.

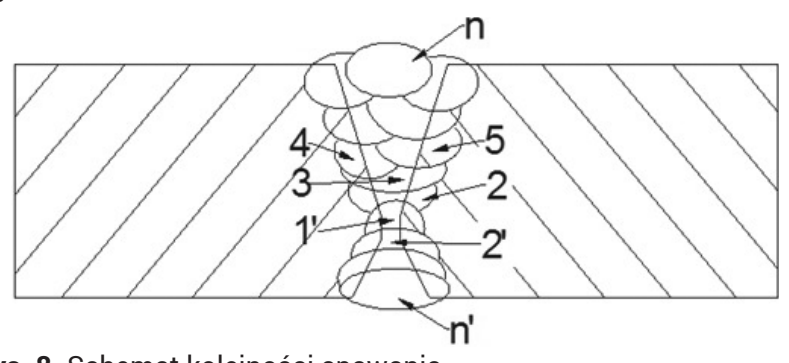

Rys. 8. Schemat kolejności spawania

Fig. 8. Scheme of welding sequence

Po ukończeniu spawania na danym styku carg przeprowadzano nakazane badania - 100\% badania VT wg PN-EN ISO 17637[8] oraz 100\% badania UT wg PN-EN ISO 17640[11]. Wymagany przez zlecającego (cementownię) poziom jakości określony został jako „B" wg PN-EN ISO 5817[10].

Badania wizualne i ultradźwiękowe przeprowadzane były przez personel posiadający uprawnienia stopnia $2 \mathrm{wg}$ PN-EN ISO 9712[7], po odczekaniu minimum 24h od zakończenia spawania. Badania przeprowadzane były przez niezależne laboratorium wskazane przez cementownię (rys. 9). Stwierdzone niezgodności zostały usunięte poprzez szlifowanie oraz ponowne spawanie. Naprawiane odcinki poddawano również 100\% kontroli w zakresie badań VT i UT przy zachowanym poziomie jakości „B”.

Do tak wyspawanego zestawu 3 carg dołączono dwie kolejne z każdej strony zestawu po jednej (rys. 2). Dalsze czynności związane z pomiarami i spawaniem wykonywano w sposób analogiczny do wyżej opisanego.

W ten sam sposób wykonano również drugi zestaw pięciu carg (rys. 10).

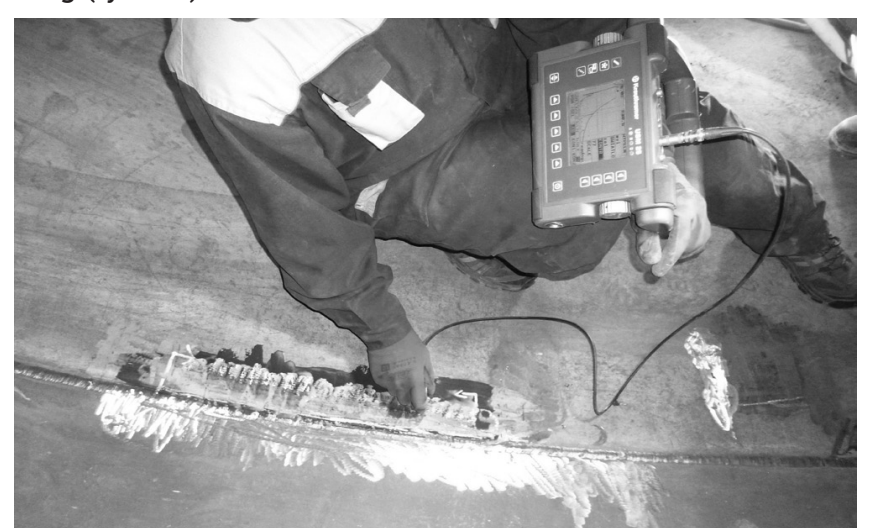

Rys. 9. Badanie ultradźwiękowe gotowego styku

Fig. 9. Ultrasonic testing the finished splice

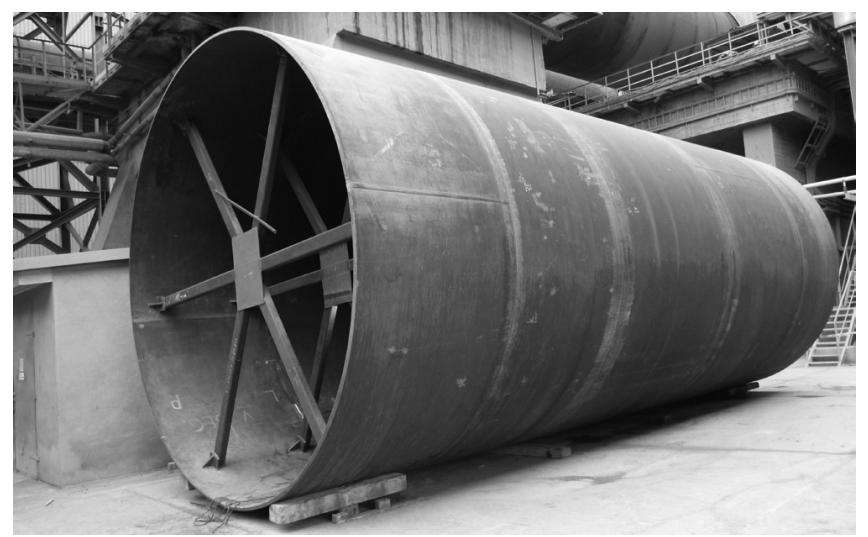

Rys. 10. Gotowy segment składający się z pięciu carg

Fig. 10. Ready segment consisting of five cargs

\section{Wycięcie odcinka pieca przewidzianego do wymiany}

Po wykonano pomiarów i wyznaczenia odcinka pieca przeznaczonego do wymiany obszar w obrębie ok. $100 \mathrm{~mm}$ od linii cięcia oczyszczono dokładnie z rdzy i innych zanieczyszczeń, a następnie wytrasowano linię cięcia płaszcza. Linię cięcia dodatkowo oznaczono co ok. 20-30 mm przy pomocy punktaka. Oznakowanie takie jest bardziej czytelne i pozwala uniknąć błędów przy cięciu cargi. Od wewnętrznej strony pieca, z której wcześniej usunięto wymurówkę ogniotrwałą, zamontowano rozpory zapobiegające deformacji płaszcza pieca. Pod piecem ustawiono stosowne podpory mające za zadanie utrzymanie $w$ niezmienionym położeniu odciętych końców walczaka. Następnie założono tor jazdy sekatora acetylenowo-tlenowego (sekator firmy Koike) i po sprawdzeniu prawidłowości jazdy wzdłuż wyznaczonej linii ciecia przeprowadzono proces cięcia pozostawiając $w$ dolnej części płaszcza odcinek ok. 1000 mm. Przy cięciu wzdłuż pierwszej linii usuwany jest pas szerokości ok $100 \mathrm{~mm}$ (rys. 11a). Zabieg ten pozwala w późniejszym etapie na swobodne usunięcie wyciętego odcinka pieca. Wymieniany odcinek usuwano w trzech osobno odcinanych fragmentach. Przy wykonaniu każdego cięcia sekatorem pozostawiano w dolnej części obwodu pieca odcinek długości ok. $1 \mathrm{~m}$.

Po podwieszeniu usuwanego odcinka pieca na zawiesiach dźwigu, odcinek ten docinany był przy pomocą palników ręcznych. Pozostające krawędzie pieca zukosowano również za pomocą sekatora (rys. 11b). Tak przygotowany brzeg oszlifowano przy pomocy szlifierki do metalicznego połysku w celu zlikwidowania nierówności i usunięcia, powstałej w wyniku cięcia, zgorzeliny. 

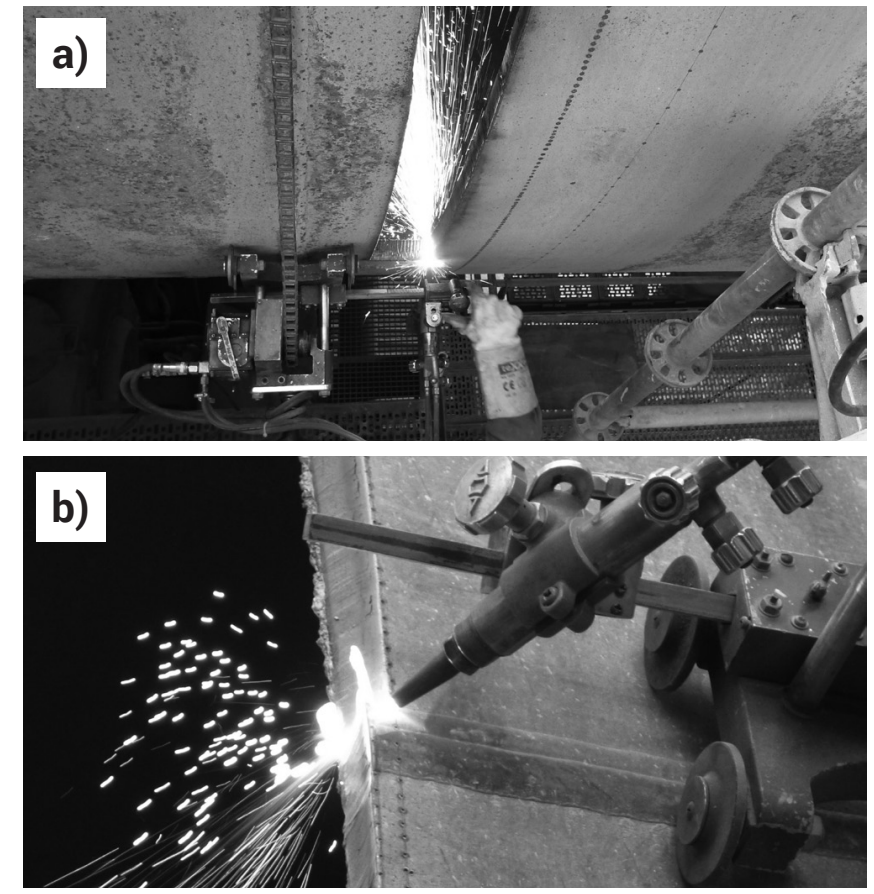

Rys. 11. Wycinanie i ukosowanie brzegów starej cargi

Fig. 11. Cutting and beveling the edges of the old segment

\section{Montaż nowych segmentów pieca}

Montaż nowych segmentów wykonano z pomocą dźwigu (rys. 12). Poszczególne segmenty mocowano za pomocą jarzm i śrub ściągających.

Tak zamontowane elementy pieca poddawane były pomiarom geodezyjnym w celu zapewnienia ich współosiowości. Za pomocą śrub ściągających wprowadzono wynikające z pomiarów korekty ustawienia elementów. W wyniku wprowadzonych korekt ulega zmianie geometria przygotowanego złącza, z szczególnie wielkość w gardzieli rowka. Zmiany te wymuszają dodatkową obróbkę poprzez szlifowanie w celu uzyskania założonej geometrii złącza (rys. 4d) oraz zapewnienia możliwości wykonania właściwej warstwy przetopowej.
Złącza przysparzające szczególnie dużych problemów podczas montażu to złącza pomiędzy "starym" fragmentem pieca, a wstawianym, nowym odcinkiem. Ze względu na deformację odcinka starego oraz różne tolerancje wykonania carg starych i nowych występują trudności z ich dopasowaniem i centrowaniem. Wymaga to zastosowania zwiększonej ilości jarzm i śrub. Ich obecność znacznie utrudnia prowadzenie procesu późniejszego żłobienia grani i spawania od wewnętrznej strony cargi.

W obszarach wykonywanych złączy zamontowano rusztowania i przy użyciu plandek brezentowych zabezpieczono je przed wpływem warunków atmosferycznych. Spoiny sczepne, warstwy przetopowe i dalsze spawanie wykonywano analogicznie jak spawanie segmentów opisane w punkcie 4 niniejszego opracowania. Oczywiście przez cały czas spawania prowadzono podgrzewanie do spawania. Wykonane złącza poddano badaniom VT i UT na $100 \%$ długości spoin, przy zachowaniu wymaganego poziomu jakości „B" wg PN-EN ISO 5817[10]. Wykryte niezgodności usunięto poprzez ich wyszlifowanie i ponowne spawanie. Odcinki naprawiane poddano ponownej kontroli VT i UT z zachowaniem wymaganego poziomu jakości „B”.

Po ukończeniu spawania i wyszlifowaniu lica spoin od wewnętrznej strony pieca ułożono ogniotrwała wymurówkę. Z chwilą ukończenia prac i dokonaniu odbiorów przez zlecającego (cementownię) piec oddano do eksploatacji.

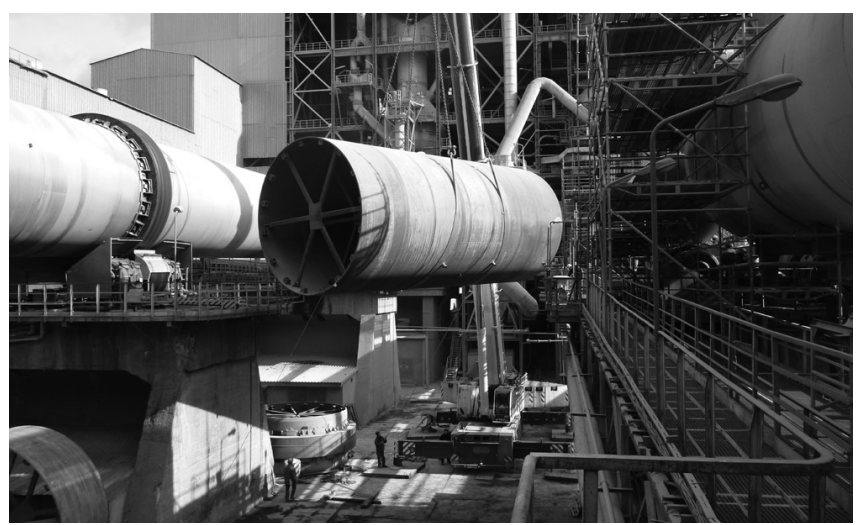

Rys. 12. Wstawianie nowych segmentów pieca

Fig. 12. Inserting new segments the kiln

\section{Wnioski}

Przy wykonywaniu prac związanych z wymianą wielkogabarytowych elementów jakimi są elementy pieca obrotowego niezmiernie ważne jest doświadczenie osób nadzorujących prace (kierownik budowy, mistrz, brygadzista, spawalnik). Pozwala to na unikniecie błędów w trakcie prowadzenia prac.

Doświadczony personel nadzoru to również zapewnienie możliwości podejmowania natychmiastowych decyzji w przypadkach wystąpienia niezgodności w trakcie prowadzonych prac.

Posiadanie własnych, doświadczonych w podobnych pracach spawaczy pozwala na skuteczne prowadzenie procesu spawania.

Rekrutacja spawaczy „zewnętrznych” musi odbywać się odpowiednio wcześniej przed rozpoczęciem prac spawalniczych.

Zatrudnienie spawaczy bez sprawdzenia ich umiejętności poprzez wykonanie i zbadanie złączy próbnych może skutkować dużą ilością niezgodności podczas procesu spawania.

Przyjęty, 12-to godzinny system pracy spawaczy powodował duże ich zmęczenie, a co za tym idzie stwarzał niebezpieczeństwo wystąpienia niezgodności w wykonywanych złączach.

Niezmiernie ważnym jest wcześniejsze przygotowanie do zabezpieczenia obszarów spawania przed wpływem warunków atmosferycznych. Dotyczy to szczególnie możliwości wystąpienia silnych wiatrów i dużych opadów deszczu lub śniegu.

\section{Literatura}

[1] PN-EN 10027-2 - Systemy oznaczania stali - System cyfrowy

[2] PN-EN 10028-2 - Wyroby płaskie ze stali na urządzenia ciśnieniowe - Część 2: Stale niestopowe i stopowe o określonych własnościach w podwyższonych temperaturach.

[3] PN-EN 287-1 - Egzamin kwalifikacyjny spawaczy - Spawanie - Część 1: Stale.

[4] PN-EN ISO 9606-1 - Egzamin kwalifikacyjny spawaczy - Spawanie - Część 1: Stale.

[5] www.metalweld.pl/polski/produkty/produkty.php?id=enzasad (05.04.2015).
[6] www.skladbaildon.pl/PDF-2012/1-pridavne-svarovaci-materialy/ D30/OK_Aristorod_1309.pdf (05.04.2015).

[7] PN-EN ISO 9712 - Badania nieniszczące - Kwalifikacja i certyfikacja personelu badań nieniszczących.

[8] PN-EN ISO 17637 - Badania nieniszczące złączy spawanych - Badania wizualne złączy spawanych.

[9] PN-EN ISO 3452 - Badania nieniszczące - Badania penetracyjne.

[10] PN-EN ISO 5817 - Spawanie - Złącza spawane ze stali, niklu, tytanu i ich stopów (z wyjątkiem spawanych wiązką) - Poziomy jakości według niezgodności spawalniczych.

[11] PN-EN ISO 17640 - Badania nieniszczące spoin - Badania ultradźwiękowe złączy spawanych. 